\title{
Research on the Factors Impact on the Cohesion in Higher Education Training between Universities and Enterprises: Case Study in Danang
}

\author{
Ngo Anh Hoang*, Nguyen Thi Hanh \\ Institute of Economic and Social Research, Duy Tan University, Vietnam
}

Received 30 November 2017

Revised 15 December 2016; Accepted 25 December 2017

\begin{abstract}
Higher education plays critical role in providing human resources to society in all areas. Universities are thriving to carry out the test of training citizens to meet social needs; exploring science and technology, bringing scientific achievements into practice to serve the industrialization and modernization of the countries. However, our higher institutions have not accomplished all of these goals; we are preferring to focus on training generations of graduates with excellent results only in their academic performance, despite the increasing demands of enterprises in reality. This research studied the factors that influence the cohesion between universities and enterprises, thereby, suggesting further feasible solutions and policies strengthening this critical relationship, shifting universities education closer to practical needs, generating high-quality employees for society, producing breakthroughs in scientific research, therefore, delivering benefits to among universities, enterprises, and society to improve linkage in geo-training in Da Nang city in particular and Central Vietnam in general.
\end{abstract}

Keywords: Universities and enterprises, influencing factors, higher education training.

\section{Introduction}

Enhancing of training quality meets demand of employability adaptation of enterprises. This issue is an important mission that to decide universities' existence, success and competition in Vietnam in particular and around the world in general. In order to exist in globalization era, the universities have to approach information of job market, demand of domestic and foreign enterprises. According to research of Nadiri, Nadiri, H., Kandampully, J\&Husain, K. (2009)

Tel.: ..............

Email: rungrotehoang@gmail.com

https://doi.org/10.25073/2588-1159/vnuer.4112 that education managers need to apply principles and strategy of marketing that they are used by manufacture and business enterprises, Therefore, the universities has recognized that a role of universities are service division, their responsibility is satisfaction of expectation and demand of student: Student and enterprises (Elliott \&Shin, 2002). Haves (1992) given factors of educational service quality such as libraries, laboratories equipment, training programs, and etc. The universities have to seek impact factors on training relationship between universities and enterprises. Gronroos (1989) said that marketing policy to be forward to development of stable relationship with 
"consumers" becausethey are resource and invaluable potential consumers for universities.

In order to resolving problems to mention above that the journal paper helps Duytan University in particular and universities in Middle of Vietnam in general to identify impact factors on a relation between universities and enterprises. The impact factors support Duytan University setting up training strategy to match on demand of enterprises.

\section{Research objective}

Research objective identify impact factors on relationship between universities and enterprises.

\section{Research methodology}

The research is implemented by quantitative method. Research data is collected from universities and 300 enterprises around Danang and Danang's neighborhood by questionnaire sheet. Modeling theory to scales design is Hang model (2012) in which the scales are ad justified to meet with research situation. The model defines as below:

Questionnaire sheet includes 3 parts, such as part 1: General information of enterprise and university, part 2: impact factors on relation of training, and part 3: information of training relation between university and enterprise is check by Likert scales (point 1: strongly disagree, point 2: disagree, point 3: wonder, point 4: agree, point 5 : strongly agree).

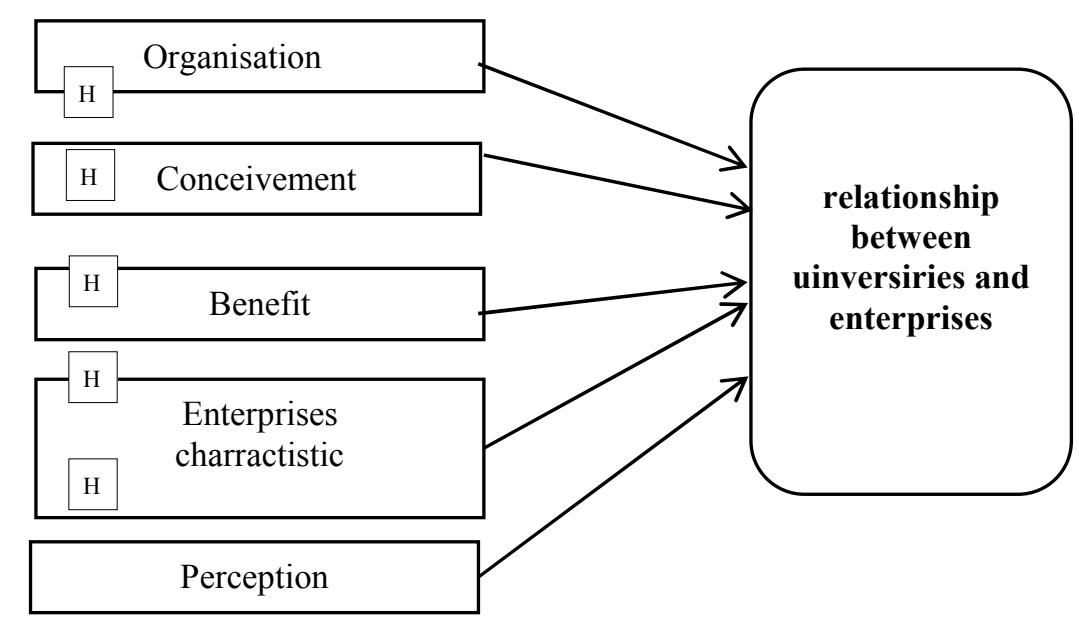

Graph 1. Research model of impact factors on relationship between universities and enterprises.

\section{Result of analysis and discussion}

\subsection{Analysis of reliability of the scale}

Reliability of the scale is accredited by Cronback's Alpha and Item - Total Correlation (see Table 1). Cronback's Alpha is used to evaluation if any observation items belong to research items.

A commonly acceptedrule for describing internal consistency using Cronbach's alpha is as follows:

\begin{tabular}{|l|l|}
\hline Cronbach's alpha & Internal consistency \\
\hline$\alpha \geq 0.9$ & $\begin{array}{l}\text { Excellent (High-Stakes } \\
\text { testing) }\end{array}$ \\
\hline $0.7 \leq \alpha<0.9$ & Good (Low-Stakes testing) \\
\hline $0.6 \leq \alpha<0.7$ & Acceptable \\
\hline $0.5 \leq \alpha<0.6$ & Poor \\
\hline$\alpha<0.5$ & Unacceptable \\
\hline
\end{tabular}


An item-total correlation test is performed to check if any item in the set of tests is inconsistent with the averaged behavior of the others, and thus can be discarded. The analysis is performed to purify the measure by eliminating 'garbage' items prior to determining the factors that represent the construct; that is, the meaning of the averaged measureitem correlation has to $>0.3$

Table 1. Result of Cronback's Alpha accreditation U

\begin{tabular}{|c|c|c|c|c|}
\hline Items & $\begin{array}{c}\text { Scale mean if to } \\
\text { skip item }\end{array}$ & $\begin{array}{l}\text { Scale variance } \\
\text { if to skip item }\end{array}$ & $\begin{array}{l}\text { Item - total } \\
\text { correction }\end{array}$ & $\begin{array}{l}\text { Cronbach's Alpha } \\
\text { if to skip item }\end{array}$ \\
\hline \multicolumn{5}{|l|}{$\begin{array}{l}\text { Alpha of benefit factor = } \\
0.739\end{array}$} \\
\hline $\begin{array}{l}\text { Not realizing the obvious } \\
\text { benefits of relation }\end{array}$ & 5.55 & 2.818 & .556 & .664 \\
\hline $\begin{array}{l}\text { Relation takes time and affects } \\
\text { the work of both parties }\end{array}$ & 6.12 & 2.564 & .646 & .555 \\
\hline Without fund for relation & 5.72 & 2.818 & .496 & .735 \\
\hline \multicolumn{5}{|l|}{$\begin{array}{l}\text { Alpha of conceivement } \\
\text { factor }=\mathbf{0 . 8 0 2}\end{array}$} \\
\hline $\begin{array}{l}\text { Define clear goals of the } \\
\text { forms of association (such as } \\
\text { attracting students, consultants } \\
\text { develop, coordinate scientific } \\
\text { research) }\end{array}$ & 8.00 & 6.818 & .542 & .788 \\
\hline $\begin{array}{l}\text { Leverage reputation/reputation } \\
\text { of partners }\end{array}$ & 7.97 & 5.669 & .588 & .767 \\
\hline $\begin{array}{l}\text { Establish a close relationship } \\
\text { (available or new) to promote } \\
\text { the image of both sides of the } \\
\text { enterprise and university }\end{array}$ & 8.08 & 5.119 & .721 & .695 \\
\hline $\begin{array}{l}\text { Awareness of ability / } \\
\text { capability, potential of partner } \\
\text { in association to promote and } \\
\text { develop }\end{array}$ & 7.84 & 5.748 & .630 & .745 \\
\hline \multicolumn{5}{|l|}{$\begin{array}{l}\text { Alpha of organisation factor } \\
=0.840\end{array}$} \\
\hline $\begin{array}{l}\text { Signing to the commitment / } \\
\text { agreement between two } \\
\text { parties }\end{array}$ & 6.44 & 4.590 & 692 & .792 \\
\hline $\begin{array}{l}\text { The ability to negotiate, } \\
\text { communicate, coordinate } \\
\text { implementation of the two } \\
\text { parties }\end{array}$ & 6.40 & 5.925 & .750 & .790 \\
\hline $\begin{array}{l}\text { Professional level in relation } \\
\text { implementation (with } \\
\text { dedicated link department) }\end{array}$ & 6.17 & 3.755 & .759 & .743 \\
\hline $\begin{array}{l}\text { Alpha of perception factor }= \\
0.811\end{array}$ & & & & \\
\hline
\end{tabular}




\begin{tabular}{|c|c|c|c|c|}
\hline Items & $\begin{array}{c}\text { Scale mean if to } \\
\text { skip item }\end{array}$ & $\begin{array}{l}\text { Scale variance } \\
\text { if to skip item } \\
\end{array}$ & $\begin{array}{l}\text { Item - total } \\
\text { correction }\end{array}$ & $\begin{array}{c}\text { Cronbach's Alpha } \\
\text { if to skip item } \\
\end{array}$ \\
\hline $\begin{array}{l}\text { Enterprise argues that } \\
\text { university research is too } \\
\text { theoretical and does not fit the } \\
\text { needs of the enterprise. }\end{array}$ & 12.08 & 8.073 & .584 & .779 \\
\hline $\begin{array}{l}\text { Enterprises do not know much } \\
\text { about the school's activities } \\
\text { because the information about } \\
\text { university's activities and } \\
\text { training is not widely } \\
\text { advertised. }\end{array}$ & 12.04 & 7.998 & .621 & .767 \\
\hline $\begin{array}{l}\text { The company believes that the } \\
\text { knowledge of the students or } \\
\text { the training program of } \\
\text { auniversity does not fit the } \\
\text { needs of enterprises. }\end{array}$ & 12.07 & 7.745 & .652 & .757 \\
\hline $\begin{array}{l}\text { Laboratories, research } \\
\text { equipment of the school are } \\
\text { backward, not suitable to the } \\
\text { needs of enterprises }\end{array}$ & 12.07 & 7.927 & .673 & .751 \\
\hline $\begin{array}{l}\text { The process of relation could } \\
\text { reveal the secrets of the } \\
\text { company }\end{array}$ & 12.28 & 9.250 & .463 & .810 \\
\hline \multicolumn{5}{|l|}{$\begin{array}{l}\text { Alpha of enterprise } \\
\text { characteristic }=0.941\end{array}$} \\
\hline $\begin{array}{l}\text { Enterprises interest in using } \\
\text { cheaper human resources than } \\
\text { high quality human resources }\end{array}$ & 23.48 & 58.616 & .670 & .938 \\
\hline $\begin{array}{l}\text { Enterprises keen on cheap } \\
\text { competition on labor markets, } \\
\text { rather than relying on } \\
\text { technology and investing in } \\
\text { new technologies }\end{array}$ & 23.29 & 53.959 & .837 & .930 \\
\hline $\begin{array}{l}\text { Enterprises do not have long- } \\
\text { term strategy on technology } \\
\text { and human development due } \\
\text { to the difficulties facing their } \\
\text { immediate business. }\end{array}$ & 23.34 & 58.408 & .608 & .941 \\
\hline $\begin{array}{l}\text { Companies do not produce the } \\
\text { final product, does not design } \\
\text { the product but usually } \\
\text { produces the input material, } \\
\text { mediates the production. }\end{array}$ & 23.61 & 57.014 & .740 & .935 \\
\hline $\begin{array}{l}\text { Enterprises do not have } \\
\text { enough facilities for students } \\
\text { to internship and practice at } \\
\text { the request of universities }\end{array}$ & 23.52 & 55.866 & .661 & .939 \\
\hline $\begin{array}{l}\text { Companies do not have } \\
\text { leading experts involved in } \\
\text { teaching at a university }\end{array}$ & 23.66 & 53.726 & .795 & .933 \\
\hline
\end{tabular}




\begin{tabular}{|c|c|c|c|c|}
\hline Items & $\begin{array}{c}\text { Scale mean if to } \\
\text { skip item }\end{array}$ & $\begin{array}{l}\text { Scale variance } \\
\text { if to skip item }\end{array}$ & $\begin{array}{l}\text { Item - total } \\
\text { correction }\end{array}$ & $\begin{array}{c}\text { Cronbach's Alpha } \\
\text { if to skip item } \\
\end{array}$ \\
\hline $\begin{array}{l}\text { Enterprises have no need for } \\
\text { scientific research or } \\
\text { development consultancy } \\
\text { from universities }\end{array}$ & 23.44 & 53.976 & .752 & .935 \\
\hline $\begin{array}{l}\text { Enterprises can not afford } \\
\text { commercialization of their } \\
\text { research products }\end{array}$ & 23.42 & 54.677 & .835 & .931 \\
\hline $\begin{array}{l}\text { There is no coherence, no } \\
\text { coordination between } \\
\text { associations to promote } \\
\text { cohesion }\end{array}$ & 23.30 & 54.100 & .834 & .931 \\
\hline $\begin{array}{l}\text { There is no support policy of } \\
\text { the authorities, local } \\
\text { authorities to promote } \\
\text { cohesion }\end{array}$ & 23.35 & 53.525 & .857 & .929 \\
\hline \multicolumn{5}{|l|}{$\begin{array}{l}\text { Alpha of training relation }= \\
0.902\end{array}$} \\
\hline $\begin{array}{l}\begin{array}{l}\text { Acceptance for students to } \\
\text { practice at enterprise }\end{array} \\
\end{array}$ & 16.57 & 34.907 & .741 & .884 \\
\hline $\begin{array}{l}\text { Organizing seminars to } \\
\text { introduce new technologies at } \\
\text { the enterprise by the school }\end{array}$ & 16.25 & 35.279 & .737 & .884 \\
\hline $\begin{array}{l}\text { Company leaders participate } \\
\text { in visiting or exchanging } \\
\text { issues related to production } \\
\text { activities of enterprises for } \\
\text { students }\end{array}$ & 16.22 & 35.176 & .755 & .882 \\
\hline \begin{tabular}{|l|} 
Enterprises supply \\
scholarships for students
\end{tabular} & 16.31 & 39.082 & .576 & .901 \\
\hline $\begin{array}{l}\text { Universities transfer } \\
\text { knowledge through training } \\
\text { programs for enterprises }\end{array}$ & 16.49 & 34.753 & .792 & .878 \\
\hline $\begin{array}{l}\text { Enterprises donates machines } \\
\text { and equipment to universities }\end{array}$ & 16.09 & 37.833 & .621 & .897 \\
\hline $\begin{array}{l}\text { Enterprises receive practical } \\
\text { training for students }\end{array}$ & 15.85 & 32.853 & .757 & .883 \\
\hline
\end{tabular}

With 31 observation items need Cronback's Alpha accreditation; therefore, the items be used for exploratory factor analysis (EFA).

\subsection{Exploratory factor analysis (EFA)}

The result of factors analysis show out KMO (Kaiser-Meyer-Olkin) coefficient that it is a creteria to use factor analysis. The result of analysis indicates $\mathrm{KMO}$ coefficient $=0.776$ and the result of Barlett's accreditation with statistic significant $=0(<0.05)$; therefore, $\mathrm{H}_{0}$ hypothesis withobservation items - correlation equal 0 in the construct that $\mathrm{H}_{0}$ will be rejected (See Table 2 ), meaning that the observation items have correlate in the construct. The sesult of showing factors analysis is appropriately.

Result of exploratory factor analysis (EFA), show in Table 3, suggests that the relationship between universitie and enterprises fits with this survey. 6 of 31 items have the factor loading smaller than 0.4 , the others ranges from 
above 0.653 to 0.901 , extraction sums squared loadings $=67.65 \%$. The factor loading is an indicator to ensuring practical significance for EFA. According to Hair and his coworkers, the factor loading greater than 0.3 reach minimum level; greater than 0.4 is acceptable; and greater than 0.5 is considered having practical value.
However, the authors assume that if the chosen factor loading is 0.3 , the sample quantitative must be at least 350. In different cases, the factor loading must be larger than 0.55 with the quantitative of 100 ; and 0.75 with $\mathrm{p} \leq 0.01$ for the quantitative of about 50 (Hair et al., 1998).

Table 2. KMO and Bartlett's Test

\begin{tabular}{|c|c|c|}
\hline \multicolumn{2}{|c|}{ Kaiser-Meyer-Olkin Measure of Sampling Adequacy. } & $\begin{array}{r}.776 \\
1451.343\end{array}$ \\
\hline \multirow{2}{*}{ Bartlett's Test of Sphericity } & df & 300 \\
\hline & Sig. & .000 \\
\hline
\end{tabular}

Table 3. Result of EFA

\begin{tabular}{|c|c|c|c|c|c|}
\hline \multirow[t]{2}{*}{ Item } & \multicolumn{5}{|c|}{ Loading* } \\
\hline & 1 & 2 & 3 & 4 & 5 \\
\hline LI1 & .785 & & & & \\
\hline LI2 & .748 & & & & \\
\hline LI3 & .722 & & & & \\
\hline TC3 & & .901 & & & \\
\hline TC2 & & .891 & & & \\
\hline TC1 & & .850 & & & \\
\hline NT3 & & & .858 & & \\
\hline NT4 & & & .797 & & \\
\hline NT2 & & & .737 & & \\
\hline NT1 & & & .720 & & \\
\hline CN4 & & & & .800 & \\
\hline CN3 & & & & .787 & \\
\hline CN2 & & & & .733 & \\
\hline CN1 & & & & .706 & \\
\hline CN5 & & & & .666 & \\
\hline DD3 & & & & & .889 \\
\hline DD8 & & & & & .885 \\
\hline DD9 & & & & & .883 \\
\hline DD10 & & & & & .882 \\
\hline DD6 & & & & & .810 \\
\hline DD4 & & & & & .797 \\
\hline DD7 & & & & & .789 \\
\hline DD2 & & & & & .759 \\
\hline DD5 & & & & & .688 \\
\hline DD1 & & & & & .653 \\
\hline & ract & act: & axi & $\begin{array}{l}\text { ig } \\
\text { zation }\end{array}$ & \\
\hline
\end{tabular}

Correlation analysis (See Table 4): Implementing to create new items that they represent for item groups and their value are average value of observation items:

NT (Representative for conceivement factor)

LI (Representative for benefit factor)

$\mathrm{CN}$ (Representative for perception factor) 
DD (Representative for enterprise characteristic factor)

TC (Representative for organization factor)

LK (Representative for training relation factor).

Table 4. Correlation among factors

\begin{tabular}{|c|c|c|c|c|c|c|c|}
\hline & & NT & $\mathrm{TC}$ & DD & $\mathrm{CN}$ & LI & LK \\
\hline \multirow[t]{2}{*}{ NT } & $\begin{array}{l}\text { Pearson's } \\
\text { correlation value }\end{array}$ & 1 & $0.205 * *$ & $0.369 * *$ & $0.218^{* *}$ & $0.162 * *$ & $0.108 * *$ \\
\hline & Sig. & & 0.000 & 0.000 & 0.000 & 0.008 & 0.002 \\
\hline \multirow{2}{*}{$\mathrm{TC}$} & $\begin{array}{l}\text { Pearson's } \\
\text { correlation value }\end{array}$ & $0.205 * *$ & 1 & $0.136 * *$ & $0.105 * *$ & $0.018 * *$ & $0.136^{* *}$ \\
\hline & Sig. & 0.000 & & 0.005 & 0.002 & 0.007 & 0.004 \\
\hline \multirow[t]{2}{*}{ DD } & $\begin{array}{l}\text { Pearson's } \\
\text { correlation value }\end{array}$ & $0.369 * *$ & $0.136 * *$ & 1 & $0.174 * *$ & $0.370^{* * *}$ & $0.419^{* *}$ \\
\hline & Sig. & 0.000 & 0.005 & & 0.004 & 0.000 & 0.000 \\
\hline \multirow[t]{2}{*}{$\mathrm{CN}$} & $\begin{array}{l}\text { Pearson's } \\
\text { correlation value }\end{array}$ & $0.218^{* *}$ & $0.105 * *$ & $0.174 * *$ & 1 & $0.227 *^{*}$ & $0.286^{* *}$ \\
\hline & Sig. & .000 & .002 & .004 & & .003 & 0.007 \\
\hline \multirow[t]{2}{*}{ LI } & $\begin{array}{l}\text { Pearson's } \\
\text { correlation value }\end{array}$ & $0.162 * *$ & $0.018 * *$ & $0.370^{* *}$ & $0.227 *^{*}$ & 1 & $0.239^{* *}$ \\
\hline & Sig. & 0.008 & 0.007 & 0.000 & 0.003 & & 0.004 \\
\hline \multirow[t]{2}{*}{ LK } & $\begin{array}{l}\text { Pearson's } \\
\text { correlation value }\end{array}$ & $0.108 * *$ & $0.136^{* *}$ & $0.419^{* *}$ & $0.286^{* *}$ & $0.239^{* *}$ & 1 \\
\hline & Sig. & 0.002 & 0.004 & 0.000 & 0.007 & 0.004 & \\
\hline
\end{tabular}

The data in Table 4 indicate sig. values $<$ 0.05; therefore, the new items have correlation and statistic significant in the research model. Thus, 5 independent items are NT, LI, CN, DD, TC factor.

\subsection{Regression analysis}

The result of regression analysis (see Table 5, Table 6, and Table 7) shows modeling of linear relationship, in which,to describe the change of dependent item of $\mathrm{Y}$ (training relation) to follow independent items of $X_{i}$ (Benefit, Conceivement, Enterprise characteristic, Organization, and Perception factors). The regression functions as below:

$Y=\beta_{0}+\beta_{1} X_{1}+\beta_{2} X_{2}+\beta_{3} X_{3}+\beta_{4} X_{4} I+\beta_{4} X_{5}$

Therein:

- $Y$ : Dependent item
- $\mathrm{X}_{\mathrm{i}}$ : Independent items

- $\beta_{0}$ : is the coefficient of expression describing the initial pitch (blocking factor) of the overall regression line

- $\beta_{\mathrm{i}}$ : is the parameter describing the slope (principal factor) of the overall regression line

- The result of regression show that:

$\mathrm{R}^{2}$ adjustment $=0.548=54.8 \%$, meaning that 5 independent items (expression items) explain $54.6 \%$ the change of dependent item of training relation of the enterprises and the universities. Durbin - Watson coefficient is used for correlence accreditation on first-order string. The result show out the model fits with multiple regression method because Durbin Watson coefficient $=2.030(0<$ the coefficient $<$ 4). The hypothesis is accepted because there is no relationship of the first-order string in the 
model. Thus, the regression model satisfies all conditions for withdraw the research result. The regression equation is not standardized as below:

$$
\mathrm{Y}=0.015+0.027 * \mathrm{X}_{1}+.0139 * \mathrm{X}_{2}+0.442
$$

$* \mathrm{X}_{3}+0.290 * \mathrm{X}_{4}+0.063 * \mathrm{X}_{5}$

The regression equation is standardizedas below:

$\mathrm{LK}=0.21 * \mathrm{NT}+0.147 * \mathrm{TC}+0.369 * \mathrm{DD}$ $+0.206 * \mathrm{CN}+0.05 * \mathrm{LI}$

From the regression equation that the researcher group gives the comment, if Conceivement factor Enterprise characteristic (DD) factorincreases up to 1value and fixes other factors that level of training relation increases 0.369 value in accordingly; if Conceivement(NT) factorincreases up to 1value and fixes other factors that level of training relation increases 0.210 value in accordingly; if Organisation (TC) factorincreases up to 1value and fixes other factors that level of training relation increases 0.147 value in accordingly; if Perception $(\mathrm{CN})$ factorincreases up to 1value and fixes other factors that level of training relation increases 0.206; if Benefit (LI) factorincreases up to 1value and fixes other factors that level of training relation increases 0.050 value in accordingly; value in accordingly.

Table 5. Summary of model

\begin{tabular}{|l|c|r|r|r|r|}
\hline Model & $\mathbf{R}$ & $\mathbf{R}^{2}$ & $\mathbf{R}^{2}$ Adjust ion & Std. Error & Durbin-Watson \\
\hline 1 & $.698^{\mathrm{a}}$ & .548 & .520 & .58211 & 2.030 \\
\hline a. Estimate factors: (constant): LI, TC, NT, CN, DD \\
\hline
\end{tabular}

Table 6. ANOVA

\begin{tabular}{|c|c|c|c|c|c|c|}
\hline \multicolumn{2}{|c|}{ Model } & \multirow{2}{*}{$\begin{array}{r}\text { Sum of square } \\
21.272\end{array}$} & \multirow{2}{*}{\begin{tabular}{r|}
$\begin{array}{c}\text { Step of } \\
\text { freedom }\end{array}$ \\
5 \\
\end{tabular}} & \multirow{2}{*}{\begin{tabular}{r|}
$\begin{array}{l}\text { Average } \\
\text { square }\end{array}$ \\
6.254
\end{tabular}} & \multirow{2}{*}{$\frac{\mathbf{F}}{35.468}$} & \multirow{2}{*}{$\begin{array}{l}\text { Sig. } \\
.000^{\mathrm{b}}\end{array}$} \\
\hline \multirow{3}{*}{1} & $\begin{array}{l}\text { Regressio } \\
n\end{array}$ & & & & & \\
\hline & $\begin{array}{l}\text { Redundan } \\
\mathrm{t}\end{array}$ & 64.583 & 295 & .278 & & \\
\hline & Total & 85.855 & 300 & & & \\
\hline
\end{tabular}

Table 7. Number of coefficient

\begin{tabular}{|c|c|c|c|c|c|c|c|c|}
\hline \multirow{2}{*}{\multicolumn{2}{|c|}{ Model }} & \multicolumn{2}{|c|}{$\begin{array}{c}\text { Unstandardized } \\
\text { coefficients }\end{array}$} & \multirow{3}{*}{$\begin{array}{c}\begin{array}{c}\text { Standardized } \\
\text { coefficients }\end{array} \\
\text { Beta }\end{array}$} & \multirow{3}{*}{$\begin{array}{c}\mathbf{t} \\
3.024\end{array}$} & \multirow{3}{*}{$\begin{array}{l}\text { Sig. } \\
.001\end{array}$} & \multicolumn{2}{|c|}{ Multicollinear } \\
\hline & & B & $\begin{array}{l}\text { Std. } \\
\text { Error }\end{array}$ & & & & Tolerance & VIF \\
\hline \multirow{4}{*}{1} & Constant & .015 & .624 & & & & & \\
\hline & NT & .027 & .124 & .021 & 1.218 & .002 & .939 & 1.065 \\
\hline & $\mathrm{CN}$ & .290 & .141 & .206 & 2.057 & .021 & .907 & 1.103 \\
\hline & LI & .063 & .133 & .050 & 1.475 & .004 & .825 & 1.211 \\
\hline
\end{tabular}

4.5. Analysis of factors to relate enterprises and universities management

4.5.1. Enterprise characteristic factor:
The result of the model indicates that the factor the strongest impact on the relation between the universities and the enterprises in Middle of Vietnam. The factor includes the observation items as below: 
a. Enterprises do not have long-term strategy on technology and human development due to the difficulties facing their immediate business;

b. Enterprises interest in using cheaper human resources than high quality human resources;

c. Enterprises keen on cheap competition on labor markets, rather than relying on technology and investing in new technologies;

d. Companies do not produce the final product, does not design the product but usually produces the input material, mediates the production;

e. Enterprises do not have enough facilities for students to internship and practice at the request of universities;

f. Companies do not have leading experts involved in teaching at a university;

g. Enterprises have no need for scientific research or development consultancy from universities;

h. Enterprises can not afford commercialization of their research products;

i. There is no coherence, no coordination between associations to promote cohesion;

k. There is no support policy of the authorities, local authorities to promote cohesion.

The factor shows that the largest issues are Middle Vietnam enterprise's competence, strategy of development and demand of development to be clearly, in the moment. Therefore, the enterprises want to improve the issue that they have to set up the start - up policies, development tendency of enterprises that become largeenterprises with their longterm and stable strategy.

With the universities, the relation with enterprises that have to calculate to divide relation proportion (for instant: lecturers and facilities is a hub of relation) or to relate with others that they are large companies and beside Middle of Vietnam or outside of Vietnam. The relation helps to break-making in the training, improving practice skill of students.

4.5.2. Concievement factor:
The factor includes the observation items as below:

a. Define clear goals of the forms of association (such as attracting students, consultants development, coordination of scientific research);

b. Leverage reputation/reputation of partners;

c. Establish a close relationship (available or new) to promote the image of both sides of the enterprise and university;

d. Awareness of ability / capability, potential of partner in association to promotion and development.

The factor shows that the core issue of between enterprises and universities introduce competence and demand of each party. Moreover, if therelation between the parties relies on support and promotion policies from Vietnam authority, the relation is strongly stable. For example, the authority asks universities are alignment with enterprise to training practice for students. The alignment supports for training and matches with demand of labor marketing.

\subsubsection{Perception factor:}

The factor includes the observation items as below:

a. Enterprise argues that university research is too theoretical and does not fit the needs of the enterprise;

b. Enterprises do not know much about the school's activities because the information about university's activities and training is not widely advertised;

c. The company believes that the knowledge of the students or the training program of a university does not fit the needs of enterprises;

d. Laboratories, research equipment of the school are backward, not suitable to the needs of enterprises;

e. The process of relation could reveal the secrets of the company.

4.5.4. Organisation factor:

The factor includes the observation items as below: 
a. Signing to the commitment / agreement between two parties;

b. The ability to negotiate, communicate, coordinate implementation of the two parties;

c. Professional level in relation implementation (with dedicated link department).

The factor shows that the impact of the factor on the relation has just relative level.It implication of professionisation in carry out the relationship such as setting up an office is charge of contract negotiation and signature,variouslynegotiable content. This is content that both of university and enterprise parties can be implementation.

4.5.5. Benefit factor:

The factor includes the observation items as below:

a. Not realizing the obvious benefits of relation;

b. Relation takes time and affects the work of both parties;

c. Without fund for relation.

The impact of the factor on cohesion between universities and enterprises parties point out problem of benefit brought, or fund or organizing implementation not being interested issue of the parties, at the moment. It is clear that finance is important force to promote the relation, but two the party just only interest in quality of training and enterprise development. Therefore, if improving the previous contents of 4 the factors that benefit factor will be improved in acridly.

\section{Conclusion}

The relation between enterprise and universities in training meeting career demand of market is crucial important problem. It decides existence, success and competitive capacity of universities in the moment. However, there are issues between Duytan University and enterprise impact the relation.

Therefore, the journal paper has researched and presented the impactfactors on between enterprises and universities, the factors consist of Benefit, Conceivement, Enterprise characteristic, Organization, and Perception factors. Through the factors that co-author of the journal paper set up the regression function as $L K=0.21 * N T+0.147 * T C+0.369 * D D$ $+0.206 * C N+0.05 * L$, the function will help Duytan University to apply to setting up strategy of relation between Duytan University and enterprises in training human resource for Danang in particular and in Middle of Vietnam in general.

\section{References}

[1] Cronin, J. J. \& Taylor, S. A (1992). Measuring service quality: A re-examination and extension Journal of Marketing. 56 (3). 55-58.

[2] Elliott, K. M. \& Shin, D. (2002). Student satisfaction: an alternative approach to assessing this important concept. Journal of Higher Education Policy and Managament, 24 (2), $197-$ 209.

[3] Gronroos, C. (1989). Defining Marketing: A Market- Oriented Approach. European Journal of Marketing, 23 (1989), 52-60.

[4] Hang, (2012. Factors that affect the linkage between Enterprises and Universities: A case study in Ho Chi Minh City.

[5] Hạnh Vân, (2007), "Trường, doanh nghiệp tìm tiếng nói chung”, theo Báo Người Lao Động.

[6] Hair, J., Black, W., Babin, B., Anderson, R., and Tatham, R. (2006). Multivariate Data Analysis $6^{\text {th }}$ ed. New Jersey: Prentice Hall.

[7] Haves, B. E. (1992). Measuring Customer Satisfation: Development and Use of Questionnaires. Wisconsin: ASQC Press.

[8] Hoàng Trọng, (2005), Phân tích dữ liệu nghiên cứu với SPSS. TP. HCM: NXB Thống kê thành phố Hồ Chí Minh.

[9] Hoàng Xuân Long, (2006), "Những nhân tố ảnh hưởng liên kết giữa viện, trường và doanh nghiệp", tạp chí KHCN , 3/2006, pp14.

[10] Nadiri, H., Kandampully, J \& Husaian, K. (2009). Student's conceivementof service quality in higher education. Total Quality Management \& Bussiness Excellence, 20(5), 523-535. 